\title{
Effect of vertical flow exchange on microbial community dis- tributions in hyporheic zones
}

\author{
School of Earth and Environmental Sciences, Seoul National University, Seoul 08826, Republic of Korea; *Corresponding author, E-mail: \\ kklee@snu.ac.kr
}

(Received: November 2, 2018; Revised accepted: January 6, 2019)

https://doi.org/10.18814/epiiugs/2019/019001

The effect of the vertical flow direction of hyporheic flux on the bacterial community is examined. Vertical velocity change of the hyporheic zone was examined by installing a piezometer on the site, and a total of 20,242 reads were analyzed using a pyrosequencing assay to investigate the diversity of bacterial communities. Proteobacteria (55.1\%) were dominant in the hyporheic zone, and Bacteroidetes (16.5\%), Actinobacteria (7.1\%) and other bacteria phylum (Firmicutes, Cyanobacteria, Chloroflexi, Planctomycetesm and unclassified phylum OD1) were identified. Also, the hyporheic zone was divided into 3 points - down welling point, mixed welling point and up welling point - through vertical hydraulic gradient, and the bacterial communities were compared and analyzed. When the species diversity index was additionally analyzed based on the pyrosequencing data, richness and diversity of species were observed to be highest in the order of mixed welling point $>$ down welling point $>$ up welling point. Hence, quantitative changes and characteristics of the hyporheic zone were analyzed to have an effect on the resident bacterial communities.

\section{Introduction}

The hyporheic zone (Kim et al., 2018) is a part of the groundwater interface in streams where a mixture of surface water and groundwater can be found. The word of hyporheic derived from Greek roots for flow (rheo) and under (hypo). This area is saturated sedimentsain which surface water and groundwater mix. There are studies of this region as a dynamic and distinguishable interface between surface water and groundwater. (Findlay, 1995; Boulton et al., 1998; Smith et al., 2008; Vogt et al., 2010; Kim et al., 2014a). Hydrologists and ecologists have approached this region with their particular perspectives. There are various literatures to identify and quantify hyporheic exchange flow (Kasahara and Wondzell, 2003; Storey et al., 2003; Cardenas et al., 2004; Westhoff et al., 2011). This water exchange is important to the hyporheic zone health because of its connection with living organisms in the zone (Boulton et al., 2010; Griebler and Avramov, 2015). The advance of hydrodynamic modeling has improved research of hydrological exchange processes at the hyporheic zone (Cardenas and Wilson, 2007; Fleckenstein et al., 2010; Endreny et al., 2011). Also, this zone has plentiful micro-organisms. The hyporheic zone constituents a dynamic hotspot (ecotone) where groundwater and surface water mix (Smith et al., 2008).

This area constitutes a flow path along which surface water down wells into the streambed sediment and groundwater up wells in the stream, travels for some distance before eventually mixing with groundwater returns to the stream channel (Hassan et al., 2015). Surface water enters the hyporheic zone when the vertical hydraulic head of surface water is greater than the groundwater (down welling). On the other hand, surface water with groundwater influence emerges from hyporheic zone where upward direction pressure of subsurface water is greater than that of the stream channel (up welling) (Kim et al., 2011).

The zone is composed of permeable gravels, sands and silts and allows significant mixing of surface water with groundwater at the zone. The area is a complicated region whose boundaries are not always easy to define. The exchange of stream water and groundwater in the hyporheic zone is dynamic in space (Kim et al., 2014a) and creates a unique community of the endemic bacteria. The exchange and mixing of groundwater and stream water plays an important role in determining the structure of bacteria diversity by influencing hydraulic and chemical condition (Zimmer and Lautz, 2015). However, there have been only a few data researches reporting on the influence of hydrologic exchange on composition and spatial distribution of the hyporheos (Jones et al., 2015). This study examines the influence of hyporheic exchange on biological characteristics of the hyporheic zone.

\section{Study site}

The study area, Haean basin is located between longitude $128^{\circ} 5^{\prime}$ $128^{\circ} 11^{\prime} \mathrm{E}$ and latitude $38^{\circ} 15^{\prime}-38^{\circ} 20^{\prime} \mathrm{N}$ with a range in altitude from ca. $339 \mathrm{~m}$ to $1,320 \mathrm{~m}$ (Fig. 1(a)). These streams leave the basin at the eastern border of the study area, where it eventually converges with Soyang River. The drainage system specifically shows a dendritic pattern. The total length of streams is about $63 \mathrm{~km}$ and the streams flow down to the depression of the basin but only one stream flows out in the east of the basin. Therefore, the hydrographic system of the area is relatively 


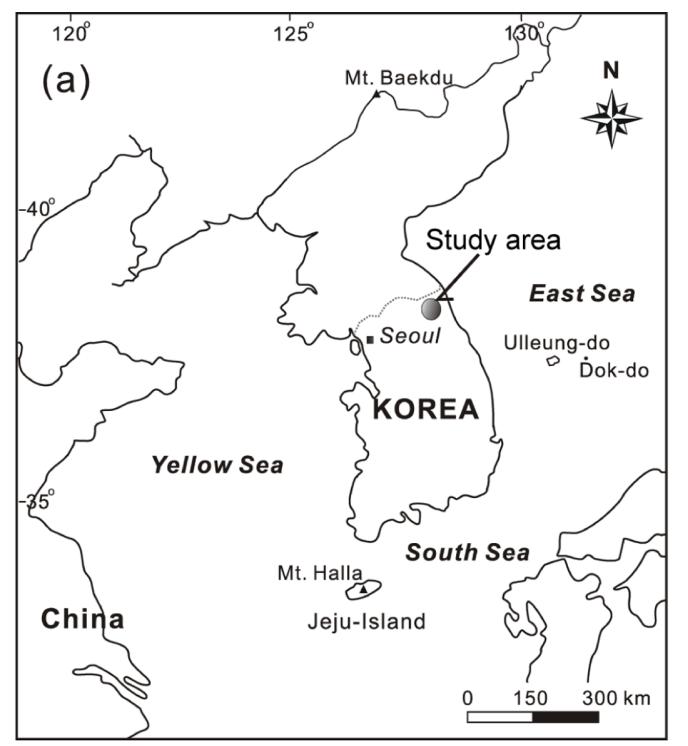

(b)
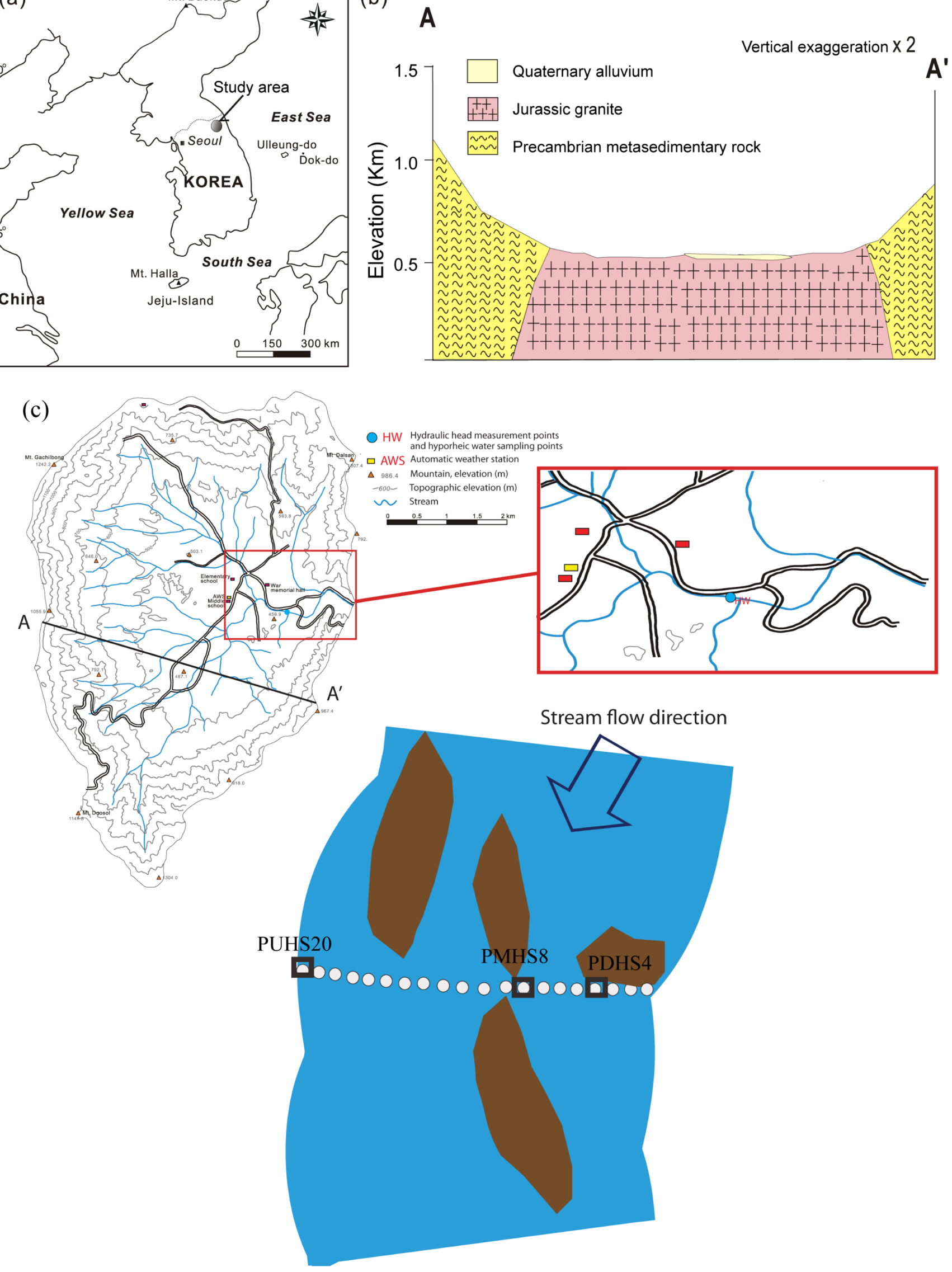

Figure 1. Location of the study area and hyporheic water sampling points. 
simple when it compares with other areas (Lee, 2009; Jeong et al., 2012; Lee et al., 2013). Geology of the study area is characterized by Jurassic igneous rocks intruding into the composite metamorphic rocks (Lee, 2009; Kim et al., 2018). The extreme region is mainly made up of alternating meta-sedimentary rocks of mica schist, biotitefeldspar gneiss and quartzite. It has peculiar and interesting topographic feature like a bowl. The features of the area have been formed through prolonged differential erosion and the depressed bottom is made up of granite only (Lee, 2009). The geological section and profile of the basin are shown in Fig. 1(b).

The climate is characterized by distinct wet and dry seasons (Kettering et al., 2012; Kim et al., 2015). From 2005 to 2014, the average annual precipitation is estimated at $1,278.5 \mathrm{~mm}$ with $50 \%$ falling during the summer monsoon (KMA, 2015). The maximum and minimum of annual precipitations were $1,557 \mathrm{~mm}$ in 2011 and $809.5 \mathrm{~mm}$ in 2014, respectively (Fig. 2). Based on the precipitations for the decade (from 2005 to 2014), the wet and dry seasons were considered to be from July to September and from October to February, respectively.

\section{Materials and Methods}

\section{Vertical hydraulic Gradient of the Hyporheic zone}

The vertical hydraulic gradient (direction and its magnitude) between groundwater and stream water was evaluated using a piezometer transect. The ambient vertical hydraulic gradient between groundwater and stream water was recorded using piezometer. The direction and magnitude of hydrologic interaction were evaluated using piezometer transects. Each piezometer was made up of 2 inch (internal diameter) PVC (polyvinyl chloride) pipe (Hyun et al., 2011; Kim et al., 2014b). At each transect, a total of 20 piezometers were inserted at $0.1 \mathrm{~m}$ depth (Kim et al., 2014a) beneath the streambed adjacent to each seepage meter installation point with a regular interval (see, Fig. 1(c)). The head was measured relative to the stream water surface and vertical hydraulic gradient was determined by dividing by the piezometer insertion depth.

$$
V H G=\frac{\Delta h}{\Delta l}
$$

where $\Delta h$ is the difference in water levels of the piezometers and stream water, $\Delta l$ is the difference in depths between streambed and the point where the piezometer is installed. However, head differences were often very small in the coarse-grained streambeds and thus, three to five measurements were averaged. The positive and negative vertical hydraulic gradients indicate up welling and down welling conditions of the hyporheic zone, respectively (Bartsch et al., 2014).

Hyporheic zone, which is the mixed zone of surface water and groundwater, is where quantitative changes occur dynamically. It was divided into 3 points for analysis through vertical hydraulic gradient in the hyporheic zone: Up welling point where the effect of groundwater is greater, down welling point where the effect of surface water is greater, and mixed welling point where quantitative changes of the groundwater and surface water were evenly observed. Fig. 3(a) shows the installed piezometer and Fig. 3(b) shows the hyporheic water sampling.

\section{Analysis of Pyrosequencing Reads}

The samples were filtered through $0.2 \mu \mathrm{m}$ filter and returned to the laboratory and stored in a $-70^{\circ} \mathrm{C}$ refrigerator until DNA extraction and pyrosequencing of $16 \mathrm{~S}$ rRNA analysis. The DNA of sampled was extracted using a FastDNA Spin Kit (Qbiogene, USA) as specified by the manufacturer. The quality of extracted DNA was checked by standard agarose gel electrophoresis and stored at $-20^{\circ} \mathrm{C}$. The DNA concentration was determined using a UV-VIS Spectrophotometer (Mechasys Co. Ltd., Korea). 16S rRNA genes were amplified using forward and inverse primers to distinguish each sample prior to sequencing at Chun Laboratory (Kim et al., 2015). Amplification condition for PCR was i) an initial denaturation step of $94^{\circ} \mathrm{C}$ or $5 \mathrm{~min}$, ii) 30 cycles of

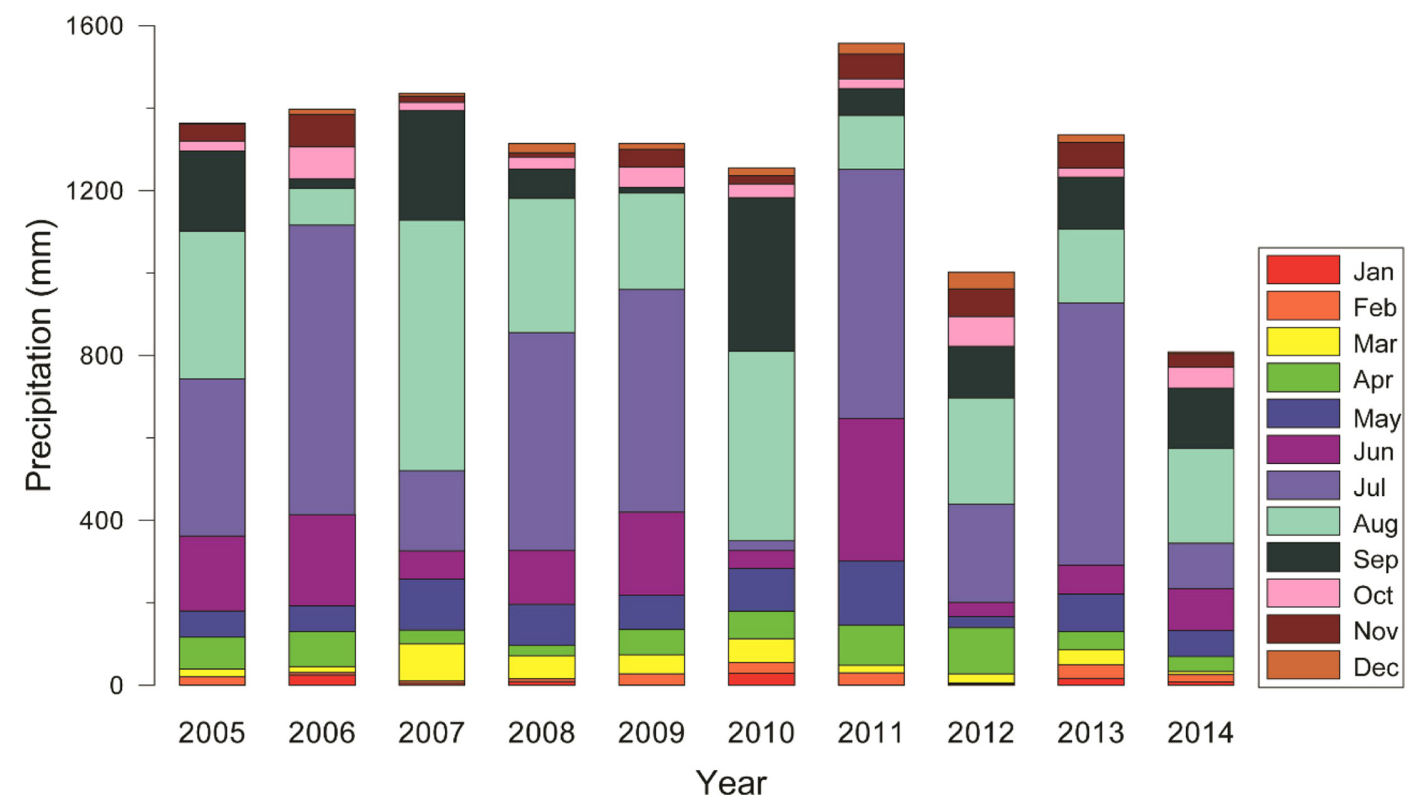

Figure 2. Annual precipitation in the study area from 2005 to 2014. 

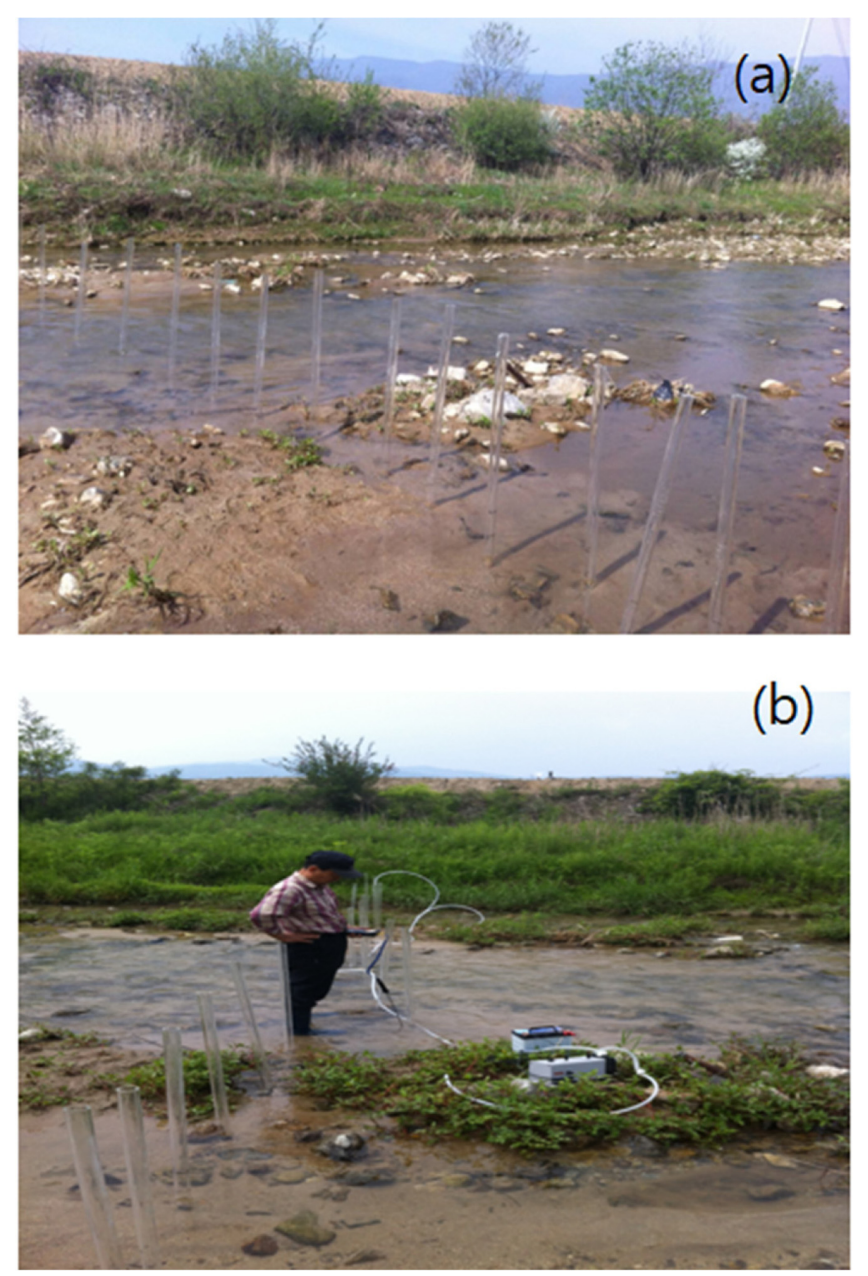

Figure 3. (a) Installed piezometers and (b) hyporheic water samplings.

denaturation, and annealing $\left(94^{\circ} \mathrm{C}\right.$ for $30 \mathrm{sec}$ followed by $55^{\circ} \mathrm{C}$ for 45 sec), and iii) an extension step at $72^{\circ} \mathrm{C}$ for $90 \mathrm{sec}$. Pyrosequencing was conducted using 454 Genome Sequence FLX Titanium Junior (Roche, NJ, USA) by Chun Laboratory (Seoul, South Korea). Distinct sequences have been deposited in the Sequence Read Archive (Chun Lab). The full sequences were analysed and compared with other known sequences that were available in the NCBI (National Center for Biotechnology Information) database. The NCBI web site can help to access to genomic information. The tools in the NCBI allow users to perform a BLAST (Basic Local Alignment Search Tool) search for similar sequences in the GenBank. A search for sequence similarities with known genes was performed using a BLAST analysis. Identification of the conserved region and protein translations and analysis of amino acids were performed using BioEdit Sequence Alignment Editor (Ibis Biosciences, USA).

Bacterial communities of down welling point (PDHS4, groundwater $<$ surface water), mixed welling point (PMHS8, groundwater $\fallingdotseq$ surface water) and up welling point (PUHS20, groundwater $>$ surface water) in the hyporheic zone were analyzed using a pyrosequencing assay. Total of 37,511 reads were analyzed in the three regions based on bacterial 16S rRNA partial gene (approximately $490 \mathrm{bp}$ ). Excluding reads where primer mismatch, non-target, low quality, short length, chimera, matching or similarity of $80 \%$ or below with eukaryotes were observed, total of 20,242 reads (PMHS8 6,065 reads, PDHS4 7,603 reads and PUHS20 6,574 reads) were analyzed (Table 1).

\section{Total Bacterial Communities}

When the bacterial communities inhabiting the hyporheic zone were analyzed at the phylum-level, Proteobacteria phylum was dominant with 11,067 reads (55.1\%), and Bacteroidetes phylum had 3,238 reads $(16.5 \%)$, Actinobacteria phylum had 1,516 reads (7.1\%), Acidobacteria phylum had 885 reads (3.9\%), Firmicutes phylum had 685 reads (3.5\%), Cyanobacteria phylum had 490 reads $(2.3 \%)$, Chloroflexi phylum had 464 reads (2.2\%), Planctomycetes phylum had 435 reads $(2.1 \%)$, and unclassified phylum OD1 had 240 reads $(1.2 \%)$. Other phylum [Gemmatimonadetes, Armatimonadetes, Verrucomicrobia, Nitrospirae, Elusimicrobia, Chlorobi, Fibrobacteres, Lentisphaerae, Fusobacteria, Deinococcus-Thermus and unclassified (TM7, GN02, TM6, OP11, OP3, MATCR, WS3, WS5, AD3 and SR1)] were identified to be lower than $1 \sim 0.05 \%$ (data below $0.05 \%$ not shown) (see, Table 1).

\section{Results and Discussion}

\section{Down Welling Point (PDHS4)}

In the down welling point which is largely affected by the surface water among the hyporheic zone, Proteobacteria phylum was dominant with $44.38 \%$, followed by Actinobacteria (14.14\%), Acidobacteria (10.75\%), Chloroflexi (6.04\%), Bacteroidetes (5.95\%), Planctomycetes $(5.55 \%)$, Firmicutes $(1.93 \%)$, Gemmatimonadetes $(1.82 \%)$, unclassified TM7 (1.33\%), Armatimonadetes (1.18\%) and Nitrospirae (1.09\%). $\alpha$-Proteobacteria class, $\delta$-Proteobacteria class, Actinobacteria phylum and Acidobacteria phylum were observed to be relatively high in the down welling point distinctively compared to mixed welling point and up welling point (Table 1 and Fig. 4).

\section{Mixed Welling Point (PMHS8)}

In the mixed welling point which is equally affected by groundwater and surface water, Proteobacteria phylum was dominant with $54.11 \%$, followed by Bacteroidetes (16.72\%), Bacteroidetes (6.56\%), Firmicutes (6.29\%), Cyanobacteria (5.85\%), unclassified OD1 (2.18\%), unclassified TM7 (1.2\%) and others (7.09\%). Mixed welling point showed dominance and percentage that are between those of down welling and up welling points, but Firmicutes phylum, Cyanobacteria phylum, and $\varepsilon$-Proteobacteria class were observed at relatively higher percentage compared to down welling and up welling points (See, Table 1 and Fig. 4).

\section{Up Welling Point (PUHS20)}

In the up welling point, Proteobacteria phylum was dominant with $66.81 \%$, followed by Bacteroidetes (26.86\%), Firmicutes (2.34\%) and others (3.99\%). Sum of Proteobacteria and Bacteroidetes phylum accounted for $93.67 \%$ of the total in the up welling point, showing a characteristic of increasing dominance compared to down welling point and mixed welling point while percentages of other phyla were 
Table 1. Analysis of bacterial diversity in the hyporheic zone (phylum-level)

\begin{tabular}{|c|c|c|c|c|c|}
\hline \multirow{2}{*}{ Phylum } & \multicolumn{3}{|c|}{$\%$ (number of reads) } & \multirow{2}{*}{ Total reads } & \multirow{2}{*}{ Ratio (\%) } \\
\hline & PDHS4 & PMHS8 & PUHS20 & & \\
\hline \multicolumn{6}{|l|}{ Proteobacteria* } \\
\hline$\alpha$-Proteobacteria & $20.79(1,581)$ & $7.75(470)$ & $1.17(77)$ & 2,128 & 10.51 \\
\hline$\beta$-Proteobacteria & $13.80(1,049)$ & $28.54(1,731)$ & $50.27(3,305)$ & 6,085 & 30.06 \\
\hline$\gamma$-Proteobacteria & $6.62(503)$ & $12.91(783)$ & $14.25(937)$ & 2,223 & 10.98 \\
\hline$\delta$-Proteobacteria & $3.09(235)$ & $2.11(128)$ & $0.53(35)$ & 398 & 1.97 \\
\hline$\varepsilon$-Proteobacteria & $0.08(6)$ & $3.12(189)$ & $0.58(38)$ & 233 & 1.15 \\
\hline Bacteroidetes & $5.95(452)$ & $16.72(1,020)$ & $26.86(1,766)$ & 3,238 & 16.00 \\
\hline Actinobacteria & $14.14(1,075)$ & $6.56(400)$ & $0.62(41)$ & 1,516 & 7.49 \\
\hline Acidobacteria & $10.75(817)$ & $0.69(42)$ & $0.40(26)$ & 885 & 4.37 \\
\hline Firmicutes & $1.93(147)$ & $6.29(384)$ & $2.34(154)$ & 685 & 3.38 \\
\hline Chloroflexi & $6.04(459)$ & $0.36(22)$ & $0.14(9)$ & 490 & 2.42 \\
\hline Planctomycetes & $5.55(422)$ & $0.49(30)$ & $0.18(12)$ & 464 & 2.29 \\
\hline Cyanobacteria & $0.83(63)$ & $5.85(357)$ & $0.23(15)$ & 435 & 2.15 \\
\hline $\mathrm{OD}^{\dagger}$ & $0.83(63)$ & $2.18(133)$ & 0.67 (44) & 240 & 1.19 \\
\hline $\mathrm{TM}^{\dagger}$ & $1.33(101)$ & $1.20(73)$ & $0.30(20)$ & 194 & 0.96 \\
\hline Gemmatimonadetes & $1.82(138)$ & $0.15(9)$ & $0.08(5)$ & 152 & 0.75 \\
\hline Armatimonadetes & $1.18(90)$ & $0.34(21)$ & $0.06(4)$ & 115 & 0.57 \\
\hline Nitrospirae & $1.09(83)$ & $0.21(13)$ & $0.03(2)$ & 98 & 0.48 \\
\hline Verrucomicrobia & $0.70(53)$ & $0.54(33)$ & $0.14(9)$ & 95 & 0.47 \\
\hline $\mathrm{GN}^{\dagger}$ & $0.33(25)$ & $0.49(30)$ & $0.26(17)$ & 72 & 0.36 \\
\hline $\mathrm{TM}^{\dagger}$ & $0.66(50)$ & $0.21(13)$ & $0.02(1)$ & 64 & 0.32 \\
\hline OP11 & $0.54(41)$ & $0.16(10)$ & $0.05(3)$ & 54 & 0.27 \\
\hline $\mathrm{OP}^{\dagger}$ & $0.17(13)$ & $0.36(22)$ & $0.09(6)$ & 41 & 0.20 \\
\hline Elusimicrobia & $0.11(8)$ & $0.38(23)$ & $0.18(12)$ & 43 & 0.21 \\
\hline Chlorobi & $0.32(24)$ & $0.21(13)$ & $0.08(5)$ & 42 & 0.21 \\
\hline MATCR $^{\dagger}$ & $0.16(12)$ & $0.28(17)$ & $0.05(3)$ & 32 & 0.16 \\
\hline $\mathrm{WS}^{\dagger}$ & $0.34(26)$ & $0.03(2)$ & $0.00(0)$ & 28 & 0.14 \\
\hline Fibrobacteres & $0.05(4)$ & $0.25(15)$ & $0.09(6)$ & 25 & 0.12 \\
\hline $\mathrm{WS}^{\dagger}$ & $0.08(6)$ & $0.18(11)$ & $0.06(4)$ & 21 & 0.10 \\
\hline Lentisphaerae & $0.05(6)$ & $0.20(12)$ & $0.03(2)$ & 18 & 0.09 \\
\hline Fusobacteria & $0.00(0)$ & $0.21(13)$ & $0.05(3)$ & 16 & 0.08 \\
\hline Deinococcus-Thermus & $0.05(4)$ & $0.11(7)$ & $0.03(2)$ & 13 & 0.06 \\
\hline $\mathrm{AD}^{\dagger}$ & $0.16(12)$ & $0.00(0)$ & $0.00(0)$ & 12 & 0.06 \\
\hline SR $1^{\dagger}$ & $0.00(0)$ & $0.10(6)$ & $0.06(4)$ & 10 & 0.05 \\
\hline Synergistetes & $0.00(0)$ & $0.11(7)$ & $0.00(0)$ & 7 & 0.03 \\
\hline Tenericutes & $0.00(0)$ & 0.07 (4) & $0.03(2)$ & 6 & 0.03 \\
\hline NKB19 & $0.04(3)$ & $0.02(1)$ & $0.02(1)$ & 5 & 0.02 \\
\hline TDNP $^{\dagger}$ & $0.00(0)$ & $0.03(2)$ & $0.03(2)$ & 4 & 0.02 \\
\hline $\mathrm{BRC}^{\dagger}$ & $0.04(3)$ & $0.00(0)$ & $0.00(0)$ & 3 & 0.01 \\
\hline $\mathrm{WS}^{\dagger}$ & $0.03(2)$ & $0.00(0)$ & $0.00(0)$ & 2 & 0.01 \\
\hline $\mathrm{GNO4}^{4}$ & $0.01(1)$ & $0.00(0)$ & $0.02(1)$ & 2 & 0.01 \\
\hline Spirochaetes & $0.03(2)$ & $0.00(0)$ & $0.00(0)$ & 2 & 0.01 \\
\hline OMAN $^{\dagger}$ & $0.01(1)$ & $0.00(0)$ & $0.00(0)$ & 1 & $<0.01$ \\
\hline $10 \mathrm{BAV}^{\dagger}$ & $0.01(1)$ & $0.00(0)$ & $0.00(0)$ & 1 & $<0.01$ \\
\hline Unidentified & $0.31(24)$ & $0.31(19)$ & $0.02(1)$ & 44 & 0.22 \\
\hline Total & 7,603 & 6,065 & 6,574 & 20,242 & 100.00 \\
\hline
\end{tabular}

*Total 11,067 reads (55.10\%) were analyzed. Details are as follows; PDHS4 (44.38\%, 3,374 reads), PMHS8 (54.11\%, 3,301 reads) and PUHS20 (66.81\%, 4,392 reads).

Unclassified phylum. 


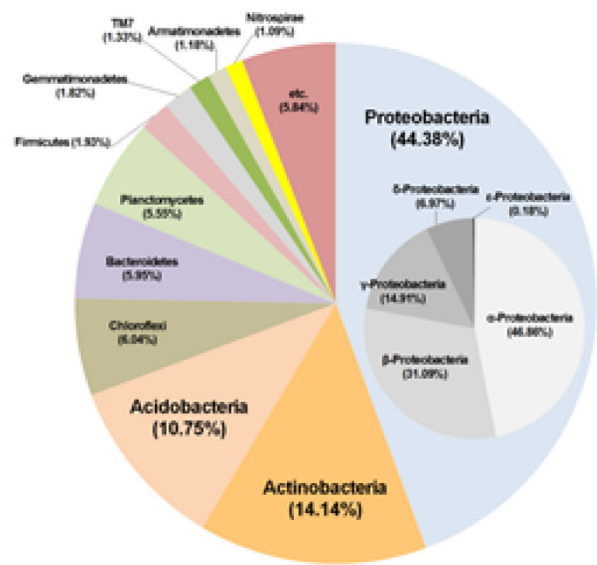

PDHS4

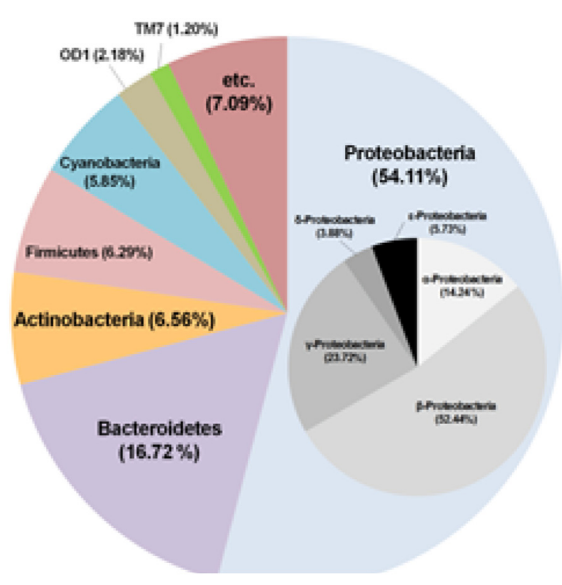

PMHS8

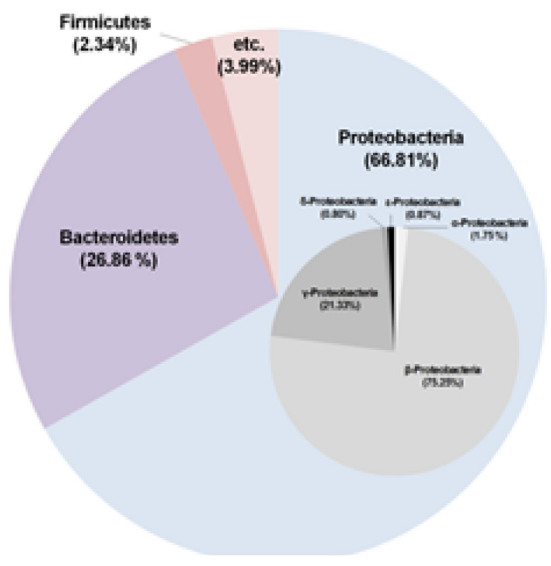

PUHS20

Figure 4. Regional bacterial diversity in the hyporheic zone (phylum-level).

low. Especially, Proteobacteria phylum (specifically $\beta$-Proteobacteria class) and Bacteroidetes phylum were high at $22.43 \%$ and $20.91 \%$, respectively, compared to the down welling point while percentages of Actinobacteria, Acidobacteria, Chloroflexi, Planctomycetes, Gemmatimonadetes, Armatimonadetes, Verrucomicrobia, Nitrospirae, Chlorobi and unidentified phylum (TM7, TM6, OP11 and WS3) were low (see, Table 1 and Fig. 4).

\section{Analysis of Bacterial Species Diversity Index}

In order to analyze bacterial species diversity in the down welling, mixed welling and up welling points, operational taxonomic unit (OTUs) and biotic diversity index (ACE, Chao1, JackKnife, NPShannon and Shannon) were analyzed (Kim et al., 2014c). In the mixed welling point, only JackKnife index was low and the rest of the diversity indices were high. In the up welling point, all indices including OTUs were low. Thereby, its species richness and diversity were evaluated as low compared to the mixed welling and down welling points. Therefore, bacterial species richness and diversity of the three regions were the highest in the order of mixed welling point $>$ down welling point $>$ up welling point (Table 2).

\section{Detailed Analysis of Dominant Bacteria in the Down Welling Point}

Actinobacteria phylum, Acidobacteria phylum, $\alpha$-Proteobacteria class and $\delta$-Proteobacteria class, which showed high percentage in the down welling point compared to up welling point were subjected to detailed analysis. Actinobacteria phylum was identified with higher percentage in the down welling point (1,075 reads, $14.14 \%)$ than the up welling point (41 reads, $0.62 \%$ ). Detailed analysis of the down welling point (1,075 reads) showed that Arthrobacter genus was dominant with 367 reads (34.14\%), and high percentage of Gaiella genus, Streptomyces genus and Cryobacterium genus were observed in the down welling point compared to the up welling point (Supplementary Table S1). Acidobacteria phylum was identified with relatively high percentage in the down welling point (817 reads, 10.75\%) compared to the up welling point ( 26 reads, $0.40 \%$ ). Detailed analysis of the down welling point ( 817 reads) showed that Blastocatella genus (132 reads) and Koribacter genus (86 reads) were dominant, and its difference with the up welling point was analyzed (Supplementary Table S2). Also, $\alpha$-Proteobacteria class had 1151 reads accounting for $46.86 \%$ among the Proteobacteria phylum in the down welling point, showing difference from $14.24 \%$ and $1.75 \%$ in the mixed welling point and up welling point, respectively. Among them, Rhizobiales order had 1006 reads showing dominance among $\alpha$-Proteobacteria class, which was different from other regions (Supplementary Table S3). Detailed analysis of $\delta$-Proteobacteria class showed 235 reads, which was relatively higher than those of the mixed welling point (128 reads) and up welling point (35 reads). Among them, Myxococcales order was dominant with 70 reads, showing difference with other regions (Supplementary Table S4).

Table 2. Diversity index of regional bacterial diversity in the hyporheic zone

\begin{tabular}{|c|c|c|c|}
\hline Diversity index & PDHS4 & PMHS8 & PUHS20 \\
\hline OTUs $^{*}$ & 3018 & 3126 & 2307 \\
\hline ACE & 7938.0 & 8491.8 & 5676.6 \\
\hline Chao1 & 5886.3 & 5991.2 & 4151.7 \\
\hline JackKnife & 9431.4 & 8771.2 & 5385.6 \\
\hline NPShannon & 7.08 & 7.18 & 6.69 \\
\hline Shannon & 6.901 & 7.019 & 6.524 \\
\hline
\end{tabular}

*OTUs were defined as groups of sequences sharing $00 \%$. 


\section{Detailed Analysis of Dominant Bacteria in the Mixed Welling Point}

Relatively high bacterial diversity was observed in the mixed welling point compared to the up welling and down welling points (see, Table 2). Analysis of the bacteria phylum (or class)-level in the mixed welling points showed high percentages of Firmicutes, Cyanobacteria, $\varepsilon$ Proteobacteria, Elusimicrobia, Lentisphaerae, Fusobacteria, Deinococcus-Thermus, Synergistetes, Tenericutes and unclassified (OD1, GN02, OP3, MATCR and WS5)compared to the up welling point and down welling point (see, Table 1). Particularly, Firmicutes (6.29\%), Cyanobacteria (5.85\%), ع-Proteobacteria (3.12\%) and unclassified OD1 (2.18\%)showed higher percentages than the means of the down welling point and up welling point, which were $2.34 \%, 0.23 \%, 0.58 \%$ and $0.75 \%$, respectively. Rest of the phyla showed percentages lower than $0.5 \%$ in the mixed welling point, but they were still relatively higher than those of the down welling or up welling point (see, Table 1).

Detailed analysis of Firmicutes phylum (384 reads) in the mixed welling point showed dominance of Firmicutes phylum with 160 reads (41.67\%) of Trichococcus genus, and66 reads (17.19\%) of Clostridium genus. Clostridiumgenus had 21 reads in the down welling point, but they were not present in the up welling point. In the mixed welling point, Acetivibrio, Acidaminobacter, Anaeromusa, Anaerosinus, Anaerosporobacter, Anaerostipes, Butyricicoccus, Carnobacterium, Coprococcus, Dendrosporobacter, Dialister, Fervidicella, Lactovum, Megamonas, Megasphaera, Oscillibacter, Phascolarctobacterium, Proteiniclasticum, Proteocatella, Pseudoflavonifractor, Ruminococcus, Saccharibacillus, Saccharofermentans, Sedimentibacter and Succinispira genus were observed that were not present in the down welling point or up welling point. Additionally, Bacillus, Virgibacillus, Alicyclobacillus, Tumebacillus, Anaerovorax, Paenisporosarcina, Dethiobacter, Sporosarcina, Dorea, Turicibacter, Planifilumand Coprococcus genus were observed in the down welling point that were not present in the mixed welling point, and only Arcobacter, Sulfurospirillum and Sulfuricurvum genus were observed in the up welling point among Firmicutes phylum, showing differences with the mixed welling point (Supplementary Table S5). Detailed analysis of Cyanobacteria phylum (357 reads) revealed 242 reads (67.79\%) of Prochlorococcus genus, and Limnococcus (46 reads), Chamaesiphon (16 reads), Pleurocapsa (13 reads), Snowella (2 reads) and Vampirovibrio genus (1 read) that were not observed in the down welling point and up welling point (Supplementary Table S6). Detailed analysis of $\varepsilon$-Proteobacteria class (189 reads) revealed Arcobacter genus (128 reads, 67.72\%), Sulfurospirillum genus (57 reads, 30.16\%), Sulfuricurvum genus (2 reads, 1.06\%) and unidentified $\varepsilon$-Proteobacteria (Campylobacterales order; 2 reads, 1.06\%) (Supplementary Table S7).

\section{Detailed Analysis of Dominant Bacteria in the up Well- ing Point}

Proteobacteria and Bacteroidetes phylum that exist at high percentage in the up welling point were analyzed in detail. Analysis of Proteobacteria phylum at the class-level revealed that $\alpha$-Proteobacteria existed in the down welling point at $20.79 \%$, which showed $19.62 \%$ difference from $1.17 \%$ in the up welling point, and $\beta$-Proteobacteria existed in the down welling point at $13.80 \%$ and in the up welling point at
$50.27 \%$, showing $30.47 \%$ difference. Additionally, $7.63 \%$ difference was observed with $\gamma$-Proteobacteria in the down welling point $(6.62 \%)$ and up welling point (14.25\%), and $2.56 \%$ difference was observed with $\delta$-Proteobacteria between the down welling point (3.09\%) and up welling point $(0.53 \%)$. These results showed differences in the bacterial diversity in the down welling point and up welling point within the hyporheic zone (Table 1). Detailed analysis of 3,305 reads of $\beta$-Proteobacteria that are dominant in the up welling point revealed 3,118 reads (94.34\%) of Burkholderiales order (Supplementary Table S8). Among them, Comamonas genus was dramatically higher in the up welling point at $60.46 \%$ than in the down welling point $(0.77 \%$ among Burkholderiales order), and the difference between Malikia genus [Down welling point (2.19\%) and Up welling point (25.53\%)] and Acidovorax genus [Down welling point $(0.90 \%)$ and Up welling point (3.08\%)] was also observed (Supplementary Table S9).

Detailed analysis of Bacteroidetes phylum revealed the difference between the up welling point and down welling point in Flavobacteria class and Sphingobacteria class. Flavobacteria class was dominant in the up welling point at 1,645 reads among 1,766 reads of Bacteroidetes phylum, accounting for $93.15 \%$, but it showed 52 reads $(11.50 \%)$ in the down welling point among 425 reads of Bacteroidetes phylum, showing difference with the up welling point (Supplementary Table S3). Detailed analysis of 1.645 reads of Flavobacteria class showed the dominance of Flavobacterium genus at 1,456 reads (88.51\%). Sphingobacteria class accounted for 372 reads $(82.30 \%)$ among Bacteroidetes phylum in the down welling point but had only 56 reads in the up welling point, showing difference in the bacterial communities between the down welling and up welling points (Supplementary Table S10).

\section{Conclusion}

Quantitative changes of the hyporheic zone were examined by installing a piezometer on the site, and a total of 20,242 reads were analyzed using a pyrosequencing assay to investigate the diversity of bacterial communities. Proteobacteria (55.1\%) were overall dominant in the hyporheic zone, and Bacteroidetes (16.5\%), Actinobacteria (7.1\%) and other bacteria phylum (Firmicutes, Cyanobacteria, Chloroflexi, Planctomycetesm and unclassified phylum OD1) were identified. Also, the hyporheic zone was divided into 3 points - down welling point, mixed welling point and up welling point - through vertical hydraulic gradient, and the bacterial communities were compared and analyzed.

In the down welling point, $\alpha$-Proteobacteria class, $\delta$-Proteobacteria class, Actinobacteria phylum and Acidobacteria phylum were relatively high compared to mixed welling point and up welling point. Arthrobacter genus in the Actinobacteria phylum, Blastocatella genus in the Acidobacteria class, Rhizobiales order in the $\alpha$-Proteobacteria class, and Myxococcales order in the $\delta$-Proteobacteria class were dominant, and the difference between mixed welling point and up welling point were observed. In the mixed welling point, Firmicutes phylum, Cyanobacteria phylum and $\varepsilon$-Proteobacteria class were identified with higher percentage compared to the down welling point and up welling point. Trichococcus genus in the Firmicutes phylum, Prochlorococcus genus in the Cyanobacteria phylum and Arcobacter genus in the $\varepsilon$-Proteobacteria class were dominant, and the difference between 
down welling point and up welling point was observed. In the mixed welling point, various species were identified that were not present in the up and down welling points.

In the up welling point, Proteobacteria and Bacteroidetes phylum were dominant, and the sum of two phyla was $93.67 \%$ indicating high dominance. Especially in $\beta$-Proteobacteria of Proteobacteria and Flavobacteria class of Bacteroidetes, which showed far higher dominance compared to the down welling point and mixed welling point, Comamonas genus and Flavobacterium genus were identified with high percentage, respectively, showing differences between the down welling point and mixed welling point. When the species diversity index was additionally analyzed based on the pyrosequencing data, richness and diversity of species were observed to be highest in the order of mixed welling point $>$ down welling point $>$ up welling point. Hence, quantitative changes and characteristics of the hyporheic zone were analyzed to have an effect on the resident bacterial communities.

The composition of bacterial communities was influenced by the direction of the vertical component of hyporheic flux. The indexes of bacterial diversity such as OUT, ACE, Cho1, NP Shannon and Shannon were low in the region where surface water or ground water were dominant, respectively. However, the indexes were the highest for the sections influenced by both surface water and groundwater.

\section{Acknowledgements}

This research was financially supported by the National Research Foundation of Korea funded by the International Collaborative Energy Technology R\&D Program of the Korea Institute of Energy Technology Evaluation and Planning (KETEP), granted financial resource from the Ministry of Trade, Industry \& Energy, Republic of Korea. (No. 20168510050070) and the National Research Council of Science \& Technology (NST) grant by the Korea government (MSIP) (No. CAP 1705 KIGAM).

\section{References}

Bartsch, S., Frei, S., Ruidisch, M., Shope, C.L., Peiffer, S., Kim, B., and Fleckenstein, J.H., 2014, River-aquifer exchange fluxes under monsoonal climate conditions. Journal of Hydrology, v. 509, pp. 601-614.

Boulton, A.J., Findlay, S., Marmonier, P., Stanley, E.H., and Valett, H.M., 1998, The functional significance of the hyporheic zone in streams and rivers. Annual Review of Ecology and Systematics, v. 29, 59-81.

Boulton, A.J., Datry, T., Kasahara, T., Mutz, M., and Stanford, J.A., 2010, Ecology and management of the hyporheic zone: stream-groundwater interactions of running waters and their floodplains. Journal of the North American Benthological Society, v. 29, pp. 26-40.

Cardenas, M.B., Wilson, J.L., and Zlotnik, V.A., 2004, Impact of heterogeneity, bed forms, and stream curvature on subchannel hyporheic exchange. Water Resources Research, v. 40, pp. 1-13.

Cardenas, M.B. and Wilson, J.L., 2007, Hydrodynamics of coupled flow above and below a sediment-water interface with triangular bedforms. Advances in water resources, v. 30, pp. 301-313.

Endreny, T., Lautz, L., and Siegel, D.I., 2011, Hyporheic flow path response to hydraulic jumps at river steps: Flume and hydrodynamic models. Water Resources Research, v.47, pp. 1-10.

Findlay, S., 1995, Importance of surface-subsurface exchange in stream ecosystems: The hyporheic zone. Limnology and oceanography, v. 40, pp. $159-164$.

Fleckenstein, J.H., Krause, S., Hannah, D.M., and Boano, F., 2010, Groundwater-surface water interactions: New methods and models to improve understanding of processes and dynamics. Advances in Water Resources, v. 33, pp. 1291-1295.

Griebler, C. and Avramov, M., 2015, Groundwater ecosystem services: a review. Freshwater Science, v. 34, pp. 355-367.

Hassan, M.A., Tonina, D., Beckie, R.D., and Kinnear, M., 2015, The effects of discharge and slope on hyporheic flow in step-pool morphologies. Hydrological Processes, v. 29, pp. 419-433.

Hyun, Y., Kim, H., Lee, S.S., and Lee, K.K., 2011, Characterizing streambed water fluxes using temperature and head data on multiple spatial scales in Munsan stream, South Korea. Journal of Hydrology, v.402, pp. 377-387.

Jeong, J.J., Bartsch, S., Fleckenstein, J.H., Matzner, E., Tenhunen, J.D., Lee, S.D., and Park, J.H., 2012, Differential storm responses of dissolved and particulate organic carbon in a mountainous headwater stream, investigated by high-frequency, in situ optical measurements. Journal of Geophysical Research: Biogeosciences, v. 117, pp. G03013.

Jones, I., Growns, I., Arnold, A., McCall, S., and Bowes, M., 2015, The effects of increased flow and fine sediment on hyporheic invertebrates and nutrients in stream mesocosms. Freshwater Biology, v. 60, pp. 813-826.

Kasahara, T. and Wondzell, S.M., 2003, Geomorphic controls on hyporheic exchange flow in mountain streams. Water Resources Research, v. 39, pp. SBH-3.

Kettering, J., Park, J.H., Lindner, S., Lee, B., Tenhunen, J., and Kuzyakov, Y., 2012, $\mathrm{N}$ fluxes in an agricultural catchment under monsoon climate: a budget approach at different scales. Agriculture, ecosystems \& environment, v.161, pp.101-111.

Kim, H., Hyun, Y., and Lee, K.K., 2011, Hydro-ecological characterization in groundwater dependent ecosystem. Journal of Korean Wetland Society, v.11, pp. 1-8 (in Korean with English abstract).

Kim, H., Lee, K.K., and Lee, J.Y., 2014a, Numerical verification of hyporheic zone depth estimation using streambed temperature. Journal of Hydrology, v. 511, pp. 861-869.

Kim, H., Lee, J.Y., Park, Y., Hyun, Y., and Lee, K.K., 2014b, Groundwater and stream water exchange revealed by water chemistry in a hyporheic zone of agricultural area. Paddy and Water Environment, v. 12, pp. 89101.

Kim, H., Lee, J.Y., and Lee, K.K., 2014c, Thermal Characteristics and Bacterial Diversity of Forest Soil in the Haean Basin of Korea. The Scientific World Journal, v. 2014, pp. ID247401.

Kim, H., Kaown, D., Mayer, B., Lee, J.Y., Hyun, Y., and Lee, K.K., 2015, Identifying the sources of nitrate contamination of groundwater in an agricultural area (Haean basin, Korea) using isotope and microbial community analyses. Science of the Total Environment, v. 533, pp. $566-575$

Kim, H., Kaown, D., Mayer, B., Lee, J.Y., and Lee, K.K., 2018, Combining pyrosequencing and isotopic approaches to assess denitrification in a hyporheic zone. Science of the Total Environment, v. 631, pp. 755764.

KMA(Korean Meteorological Administration), 2015, Homepage of Korean Meteorological Administration. http://www.kma.go.kr [accessed on $30^{\text {th }}$ October 2018].

Lee, J.Y., 2009, Importance of hydrogeological and hydrologic studies for Haean basin in Yanggu. Journal of Geological Society of Korea v. 45, pp. 405-414 (in Korean with English abstract).

Lee, J.Y., Lee, K.S., Park, Y., Choi, H.M., and Jo, Y.J., 2013, Chemical and isotopic compositions of groundwater and stream water in a heavy agricultural basin of Korea. Journal of the Geological Society of India, v. 82 , pp. $169-180$

Smith, J.W.N., Bonell, M., Gibert, J., McDowell, W.H., Sudicky, E.A., Turner, J.V., and Harris, R.C., 2008, Groundwater-surface water interactions, nutrient fluxes and ecological response in river corridors: 
translating science into effective environmental management. Hydrological Processes, v. 22, pp. 151-157.

Storey, R.G., Howard, K.W., and Williams, D.D., 2003, Factors controlling riffle-scale hyporheic exchange flows and their seasonal changes in a gaining stream: A three-dimensional groundwater flow model. Water Resources Research, v. 39, pp. 1-17.

Vogt, T., Schneider, P., Hahn-Woernle, L., and Cirpka, O.A., 2010, Estimation of seepage rates in a losing stream by means of fiber-optic highresolution vertical temperature profiling. Journal of Hydrology, v. 380, pp. 154-164.

Westhoff, M.C., Gooseff, M.N., Bogaard, T.A., and Savenije, H.H.G., 2011, Quantifying hyporheic exchange at high spatial resolution using natural temperature variations along a first-order stream. Water Resources Research, v. 47, pp. 1-13.

Zimmer, M.A. and Lautz, L.K., 2015, Pre-and postrestoration assessment of stream water-groundwater interactions: effects on hydrological and chemical heterogeneity in the hyporheic zone. Freshwater Science, v. $34,287-300$.

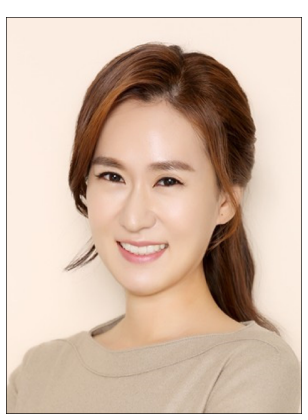

Heejung Kim is a research professor of hydrogeology in Seoul National University, Korea. She received her M.S. degree from School of Earth and Environmental Sciences, Seoul National University, Korea. She earned her B.S. degree of Environmental Science and Engineering at Ewha Womans University, Korea. She was awarded the 2018 young geologist from the Geological Society of Korea. Her research interests include groundwater-stream water interaction, delineation study of hyporheic zone, and microbial diversity in soil and groundwater.

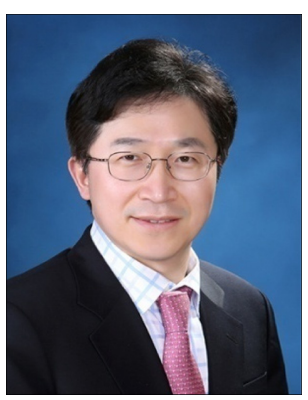

Kang-Kun Lee is a full professor of Hydrogeology and an associate dean of the College of Science at Seoul National University, Korea. He received his Ph.D. from Purdue University, West Lafayette, USA. He has been studying groundwater in Korea since he joined Seoul National University in 1993 . He was awarded a medal from the Korean Government at the national ceremony for World Water Day in 2011. He was the president of the Korean Society of Soil and Groundwater Environment during 2011-2012 and is currently serving as a president of the Geological Society of Korea. He has served as editor in chief for Geosciences Journal, associate editors for Journal of Hydrology and Hydrogeology Journal, and national representative of the International Association of Hydrological Sciences. 


\section{Supplementary}

Table S1. Detailed analysis of Actinobacteria genus in hyporheic zones

\begin{tabular}{|c|c|c|c|}
\hline \multirow{2}{*}{ Genus } & \multicolumn{3}{|c|}{ Number of reads } \\
\hline & PDHS4 & PMHS8 & PUHS20 \\
\hline 4P003540_g & 2 & 0 & 0 \\
\hline AB021325_g & 4 & 3 & 0 \\
\hline AB240334_g & 3 & 0 & 0 \\
\hline AB245397_g & 2 & 0 & 0 \\
\hline AB630582_g & 17 & 0 & 0 \\
\hline AcI_B_g & 0 & 1 & 0 \\
\hline Aciditerrimonas & 1 & 0 & 0 \\
\hline Actinoallomurus & 2 & 0 & 0 \\
\hline Actinomadura & 1 & 0 & 0 \\
\hline Actinoplanes & 4 & 6 & 0 \\
\hline Aeromicrobium & 1 & 0 & 0 \\
\hline AF408985_g & 1 & 0 & 0 \\
\hline AF498716_g & 2 & 0 & 0 \\
\hline AJ507468_g & 0 & 1 & 0 \\
\hline AJ863193_g & 1 & 0 & 0 \\
\hline Alpinimonas & 6 & 8 & 0 \\
\hline AM277063_g & 1 & 1 & 0 \\
\hline AM991247_g & 110 & 1 & 1 \\
\hline Amnibacterium & 1 & 0 & 0 \\
\hline Angustibacter & 2 & 0 & 0 \\
\hline Aquiluna & 2 & 29 & 2 \\
\hline Arthrobacter & 367 & 15 & 4 \\
\hline Asanoa & 1 & 0 & 0 \\
\hline AY234624_g & 0 & 0 & 1 \\
\hline Brooklawnia & 2 & 0 & 0 \\
\hline Cellulomonas & 0 & 1 & 0 \\
\hline Chryseoglobus & 0 & 1 & 0 \\
\hline Collinsella & 0 & 0 & 2 \\
\hline Conexibacter & 7 & 0 & 0 \\
\hline Corynebacterium & 0 & 1 & 0 \\
\hline Cryobacterium & 25 & 0 & 0 \\
\hline Demequina & 0 & 0 & 1 \\
\hline DQ125551_g & 2 & 0 & 1 \\
\hline EF016795_g & 1 & 0 & 0 \\
\hline EF018137_g & 0 & 1 & 0 \\
\hline EF516392_g & 1 & 1 & 0 \\
\hline EF516411_g & 1 & 0 & 0 \\
\hline
\end{tabular}

Table S1. (continued)

\begin{tabular}{|c|c|c|c|}
\hline \multirow{2}{*}{ Genus } & \multicolumn{3}{|c|}{ Number of reads } \\
\hline & PDHS4 & PMHS8 & PUHS20 \\
\hline EF516773_g & 1 & 0 & 1 \\
\hline EF520360_g & 2 & 0 & 0 \\
\hline EF584530_g & 0 & 0 & 1 \\
\hline EF632905_g & 10 & 0 & 0 \\
\hline EU289467_g & 1 & 0 & 0 \\
\hline EU335168_g & 1 & 0 & 0 \\
\hline EU374107_g & 0 & 1 & 0 \\
\hline EU801210_g & 2 & 5 & 0 \\
\hline EU861899_g & 14 & 0 & 0 \\
\hline EU861937_g & 3 & 0 & 0 \\
\hline EU980607_g & 2 & 0 & 0 \\
\hline FJ478790_g & 1 & 0 & 0 \\
\hline FJ478799_g & 25 & 0 & 2 \\
\hline FM209069_g & 3 & 0 & 1 \\
\hline FM886842_g & 1 & 0 & 1 \\
\hline FN436189_g & 1 & 0 & 0 \\
\hline FN554394_g & 5 & 0 & 0 \\
\hline FN687458_g & 6 & 0 & 0 \\
\hline FN811204_g & 10 & 0 & 0 \\
\hline Friedmanniella & 1 & 0 & 0 \\
\hline Frigoribacterium & 0 & 1 & 0 \\
\hline Gaiella & 95 & 5 & 1 \\
\hline Gordonibacter & 0 & 2 & 0 \\
\hline GQ387490_g & 34 & 26 & 0 \\
\hline GQ396807_g & 4 & 1 & 0 \\
\hline GQ396959_g & 2 & 0 & 1 \\
\hline GQ487899_g & 3 & 0 & 0 \\
\hline GU305765_g & 13 & 0 & 1 \\
\hline Herbiconiux & 0 & 1 & 0 \\
\hline HM445971_g & 0 & 4 & 0 \\
\hline HM748665_g & 6 & 0 & 0 \\
\hline HQ674860_g & 1 & 1 & 0 \\
\hline HQ864103_g & 0 & 1 & 0 \\
\hline HQ910322_g & 1 & 0 & 0 \\
\hline Humibacillus & 1 & 0 & 0 \\
\hline Ilumatobacter & 6 & 0 & 0 \\
\hline Jatrophihabitans & 8 & 0 & 0 \\
\hline
\end{tabular}


Table S1. (continued)

\begin{tabular}{|c|c|c|c|}
\hline \multirow{2}{*}{ Genus } & \multicolumn{3}{|c|}{ Number of reads } \\
\hline & PDHS4 & PMHS8 & PUHS20 \\
\hline JN588609_g & 2 & 0 & 0 \\
\hline Kitasatospora & 11 & 1 & 0 \\
\hline Knoellia & 1 & 0 & 0 \\
\hline Leifsonia & 0 & 0 & 2 \\
\hline Leucobacter & 0 & 1 & 0 \\
\hline Longispora & 1 & 0 & 0 \\
\hline Lysinimonas & 1 & 0 & 0 \\
\hline Marmoricola & 1 & 0 & 0 \\
\hline Microbacterium & 9 & 5 & 0 \\
\hline Micrococcus & 0 & 1 & 0 \\
\hline Microlunatus & 2 & 0 & 0 \\
\hline Micromonospora & 2 & 1 & 0 \\
\hline Microterricola & 3 & 1 & 0 \\
\hline Mycobacterium & 21 & 0 & 4 \\
\hline Nakamurella & 9 & 0 & 0 \\
\hline Nocardia & 2 & 0 & 0 \\
\hline Nocardioides & 24 & 5 & 0 \\
\hline Nocardiopsis & 1 & 0 & 0 \\
\hline Nonomuraea & 2 & 0 & 0 \\
\hline Oryzihumus & 27 & 1 & 0 \\
\hline Phycicoccus & 20 & 0 & 0 \\
\hline Planktoluna & 2 & 6 & 0 \\
\hline Planktophila & 12 & 208 & 7 \\
\hline Propioniciclava & 2 & 2 & 2 \\
\hline Propionicimonas & 3 & 1 & 2 \\
\hline Rhodococcus & 6 & 1 & 0 \\
\hline Rhodoluna & 9 & 43 & 2 \\
\hline Saccharomonospora & 1 & 0 & 0 \\
\hline Salinibacterium & 2 & 1 & 0 \\
\hline Sanguibacter & 0 & 2 & 0 \\
\hline Sinomonas & 1 & 0 & 0 \\
\hline Streptomyces & 44 & 0 & 0 \\
\hline Streptosporangium & 1 & 0 & 0 \\
\hline Terrabacter & 14 & 0 & 0 \\
\hline Tetrasphaera & 5 & 2 & 1 \\
\hline Tropheryma & 1 & 0 & 0 \\
\hline Total & 1,075 & 400 & 41 \\
\hline
\end{tabular}

Table S2. Detailed analysis of Acidobacteria genus in hyporheic zones

\begin{tabular}{|c|c|c|c|}
\hline \multirow{2}{*}{ Genus } & \multicolumn{3}{|c|}{ Number of reads } \\
\hline & PDHS4 & PMHS8 & PUHS20 \\
\hline AB179509_g & 2 & 0 & 0 \\
\hline AB240310_g & 5 & 0 & 0 \\
\hline AB252946_g & 5 & 0 & 0 \\
\hline AB355055_g & 9 & 0 & 0 \\
\hline Acidobacterium & 4 & 0 & 0 \\
\hline AF234701_g & 3 & 0 & 0 \\
\hline AM180888_g & 7 & 0 & 0 \\
\hline AY212581_g & 1 & 0 & 0 \\
\hline AY281358_g & 52 & 0 & 0 \\
\hline AY921986_g & 1 & 0 & 0 \\
\hline Blastocatella & 132 & 6 & 0 \\
\hline Bryobacter & 2 & 0 & 0 \\
\hline DQ083303_g & 0 & 1 & 0 \\
\hline DQ139454_g & 1 & 0 & 0 \\
\hline DQ451510_g & 5 & 0 & 0 \\
\hline DQ453805_g & 15 & 0 & 0 \\
\hline DQ648914_g & 8 & 0 & 0 \\
\hline DQ829648_g & 4 & 0 & 0 \\
\hline DQ833485_g & 4 & 0 & 0 \\
\hline DQ906882_g & 1 & 0 & 0 \\
\hline Edaphobacter & 2 & 0 & 0 \\
\hline EF492943_g & 1 & 0 & 0 \\
\hline EF999370_g & 0 & 1 & 0 \\
\hline EU192989_g & 4 & 0 & 0 \\
\hline EU335275_g & 15 & 1 & 0 \\
\hline EU373937_g & 1 & 0 & 0 \\
\hline EU445199_g & 11 & 0 & 0 \\
\hline EU652507_g & 4 & 0 & 0 \\
\hline EU676413_g & 1 & 0 & 0 \\
\hline EU686607_g & 16 & 0 & 0 \\
\hline EU861837_g & 1 & 0 & 0 \\
\hline EU881271_g & 1 & 0 & 0 \\
\hline FJ416115_g & 2 & 0 & 0 \\
\hline FJ478829_g & 5 & 0 & 0 \\
\hline FJ478953_g & 7 & 0 & 0 \\
\hline FJ479026_g & 8 & 0 & 0 \\
\hline FJ479597_g & 2 & 0 & 0 \\
\hline GQ214092_g & 1 & 0 & 0 \\
\hline GQ302594_g & 2 & 0 & 1 \\
\hline
\end{tabular}


Table S2. (continued)

\begin{tabular}{|c|c|c|c|}
\hline \multirow{2}{*}{ Genus } & \multicolumn{3}{|c|}{ Number of reads } \\
\hline & PDHS4 & PMHS8 & PUHS20 \\
\hline GQ472805_g & 7 & 0 & 1 \\
\hline Granulicella & 3 & 0 & 0 \\
\hline GU127807_g & 1 & 0 & 0 \\
\hline GU187031_g & 64 & 3 & 3 \\
\hline GU187034_g & 1 & 0 & 0 \\
\hline GU260705_g & 79 & 5 & 2 \\
\hline GU727715_g & 1 & 0 & 0 \\
\hline HM061812_g & 8 & 1 & 0 \\
\hline HM131972_g & 3 & 0 & 0 \\
\hline HM243779_g & 2 & 0 & 0 \\
\hline HM243842_g & 2 & 0 & 0 \\
\hline HM445331_g & 29 & 3 & 0 \\
\hline HM748715_g & 1 & 0 & 0 \\
\hline Holophaga & 6 & 6 & 7 \\
\hline HQ010775_g & 3 & 0 & 0 \\
\hline HQ166644_g & 1 & 0 & 0 \\
\hline HQ190378_g & 2 & 0 & 0 \\
\hline HQ190410_g & 19 & 5 & 2 \\
\hline HQ190481_g & 6 & 0 & 0 \\
\hline HQ445629_g & 2 & 0 & 0 \\
\hline HQ445649_g & 3 & 0 & 0 \\
\hline HQ445680_g & 7 & 4 & 1 \\
\hline HQ445759_g & 0 & 1 & 1 \\
\hline HQ645210_g & 9 & 0 & 0 \\
\hline HQ864177_g & 8 & 0 & 0 \\
\hline JF429092_g & 1 & 0 & 0 \\
\hline JF718667_g & 8 & 0 & 0 \\
\hline Koribacter & 86 & 0 & 3 \\
\hline Solibacter & 28 & 0 & 0 \\
\hline Telmatobacter & 2 & 0 & 0 \\
\hline Z95718_g & 6 & 0 & 0 \\
\hline Z95727_g & 73 & 5 & 5 \\
\hline Z95729_g & 1 & 0 & 0 \\
\hline Total & 817 & 42 & 26 \\
\hline
\end{tabular}

Table S3. Detailed analysis of a-Proteobacteria order in hyporheic zones

\begin{tabular}{|c|c|c|c|}
\hline \multirow{2}{*}{ Order } & \multicolumn{3}{|c|}{$\%$ (number of reads) } \\
\cline { 2 - 4 } & PDHS4 & PMHS8 & PUHS20 \\
\hline AY957891_o & $0.13(2)$ & $0.42(2)$ & $0(0)$ \\
\hline Caulobacterales & $2.97(47)$ & $4.68(22)$ & $3.9(3)$ \\
\hline EF573150_o & $0.32(5)$ & $0.42(2)$ & $0(0)$ \\
\hline FJ612212_o & $0(0)$ & $0.21(1)$ & $0(0)$ \\
\hline Kordiimonadales & $0(0)$ & $0.21(1)$ & $1.3(1)$ \\
\hline Micavibrio_o & $0.13(2)$ & $2.13(10)$ & $1.3(1)$ \\
\hline Parvularculales & $0.06(1)$ & $0(0)$ & $0(0)$ \\
\hline Rhizobiales & $63.63(1006)$ & $21.49(101)$ & $29.87(23)$ \\
\hline Rhodobacterales & $8.41(133)$ & $17.03(80)$ & $27.28(21)$ \\
\hline Rhodospirillales & $10.50(166)$ & $10.64(50)$ & $6.49(5)$ \\
\hline Rickettsiales & $1.58(25)$ & $12.77(60)$ & $9.09(7)$ \\
\hline Sphingomonadales & $12.27(194)$ & $30(141)$ & $20.77(16)$ \\
\hline Total & 1,581 & 470 & 77 \\
\hline
\end{tabular}

Table S4. Detailed analysis of $\delta$-Proteobacteria order in hyporheic zones

\begin{tabular}{|c|c|c|c|}
\hline \multirow{2}{*}{ Order } & \multicolumn{3}{|c|}{$\%$ (number of reads) } \\
\cline { 2 - 4 } & PDHS4 & PMHS8 & PUHS20 \\
\hline AF269002_o & $1.28(3)$ & $0.00(0)$ & $0.00(0)$ \\
\hline AY921748_o & $0.00(0)$ & $0.78(1)$ & $0.00(0)$ \\
\hline Bdellovibrionales & $2.13(5)$ & $10.16(13)$ & $5.71(2)$ \\
\hline CU925466_o & $15.33(36)$ & $6.25(8)$ & $8.57(3)$ \\
\hline Deferrisoma_o & $0.42(1)$ & $0.00(0)$ & $0.00(0)$ \\
\hline Desulfobacca_o & $0.00(0)$ & $0.00(0)$ & $2.85(1)$ \\
\hline Desulfobacterales & $0.85(2)$ & $0.78(1)$ & $0.00(0)$ \\
\hline Desulfobulbaceae_o & $0.00(0)$ & $0.78(1)$ & $0.00(0)$ \\
\hline Desulfovibrionales & $0.00(0)$ & $3.91(5)$ & $2.85(1)$ \\
\hline Desulfuromonadales & $5.11(12)$ & $3.91(5)$ & $2.85(1)$ \\
\hline EF574244_o & $0.85(2)$ & $0.78(1)$ & $0.00(0)$ \\
\hline EU335163_o & $0.42(1)$ & $0.00(0)$ & $0.00(0)$ \\
\hline EU617842_o & $0.85(2)$ & $0.00(0)$ & $0.00(0)$ \\
\hline EU861868_o & $1.28(3)$ & $5.47(7)$ & $0.00(0)$ \\
\hline FJ889281_o & $7.66(18)$ & $21.09(27)$ & $51.45(18)$ \\
\hline FM253572_o & $23.84(56)$ & $2.34(3)$ & $0.00(0)$ \\
\hline GU567808_o & $0.42(1)$ & $2.34(3)$ & $0.00(0)$ \\
\hline HM243977_o & $0.42(1)$ & $0.78(1)$ & $0.00(0)$ \\
\hline Myxococcales & $29.79(70)$ & $21.88(28)$ & $8.57(3)$ \\
\hline OM27 & $0.42(1)$ & $0.78(1)$ & $2.85(1)$ \\
\hline SAR324 & $0.00(0)$ & $0.78(1)$ & $0.00(0)$ \\
\hline Spirobacillus_o & $8.09(19)$ & $17.19(22)$ & $14.3(5)$ \\
\hline Syntrophobacterales & $0.42(1)$ & $0.00(0)$ & $0.00(0)$ \\
\hline Syntrophorhabdaceae_o & $0.42(1)$ & $0.00(0)$ & $0.00(0)$ \\
\hline Total & 235 & 128 & 35 \\
\hline
\end{tabular}


Table S5. Detailed analysis of Firmicutes genus in hyporheic zones

\begin{tabular}{|c|c|c|c|}
\hline \multirow{2}{*}{ Genus } & \multicolumn{3}{|c|}{ Number of reads } \\
\hline & PDHS4 & PMHS8 & PUHS20 \\
\hline AB237727_g & 0 & 1 & 0 \\
\hline Acetivibrio & 0 & 1 & 0 \\
\hline Acidaminobacter & 0 & 3 & 0 \\
\hline AF304435_g & 0 & 2 & 0 \\
\hline AM183112_g & 0 & 1 & 0 \\
\hline AM406061_g & 0 & 2 & 0 \\
\hline AM500748_g & 0 & 3 & 0 \\
\hline Anaeromusa & 0 & 1 & 0 \\
\hline Anaerosinus & 0 & 1 & 0 \\
\hline Anaerosporobacter & 0 & 2 & 0 \\
\hline Anaerostipes & 0 & 3 & 0 \\
\hline AY532583_g & 0 & 1 & 0 \\
\hline Blautia & 3 & 2 & 0 \\
\hline Butyricicoccus & 0 & 1 & 0 \\
\hline Carnobacterium & 0 & 2 & 0 \\
\hline Clostridium & 11 & 53 & 0 \\
\hline Clostridium_g22 & 0 & 3 & 0 \\
\hline Clostridium g25 & 0 & 2 & 0 \\
\hline Clostridium_g4 & 10 & 6 & 0 \\
\hline Clostridium_g7 & 0 & 1 & 0 \\
\hline Clostridium_g9 & 0 & 1 & 0 \\
\hline Coprococcus_g2 & 0 & 1 & 0 \\
\hline D16279_g & 0 & 1 & 0 \\
\hline Dendrosporobacter & 0 & 1 & 0 \\
\hline Dialister & 0 & 1 & 0 \\
\hline DQ071484_g & 1 & 3 & 0 \\
\hline DQ206415_g & 0 & 1 & 0 \\
\hline DQ777915_g & 0 & 1 & 0 \\
\hline EF403870_g & 1 & 1 & 0 \\
\hline EF404752_g & 0 & 1 & 0 \\
\hline EU753611_g & 0 & 1 & 0 \\
\hline EU845632_g & 0 & 4 & 0 \\
\hline Eubacterium_g2 & 2 & 2 & 0 \\
\hline Exiguobacterium & 5 & 4 & 0 \\
\hline Faecalibacterium & 1 & 4 & 0 \\
\hline Fervidicella & 0 & 2 & 0 \\
\hline FJ799146_g & 0 & 1 & 0 \\
\hline FJ880290_g & 0 & 2 & 0 \\
\hline GQ406188_g & 0 & 3 & 0 \\
\hline GQ871709_g & 1 & 1 & 0 \\
\hline GU112184_g & 0 & 2 & 0 \\
\hline GU324404_g & 1 & 1 & 0 \\
\hline GU454868_g & 0 & 1 & 0 \\
\hline HM123979_g & 0 & 1 & 0 \\
\hline HQ132444_g & 0 & 1 & 0 \\
\hline HQ904156_g & 0 & 2 & 0 \\
\hline Lactobacillus & 2 & 6 & 0 \\
\hline Lactococcus & 3 & 12 & 0 \\
\hline Lactovum & 0 & 1 & 0 \\
\hline Leuconostoc & 1 & 7 & 0 \\
\hline Megamonas & 0 & 7 & 0 \\
\hline
\end{tabular}

Table S5. (continued)

\begin{tabular}{|c|c|c|c|}
\hline \multirow{2}{*}{ Genus } & \multicolumn{3}{|c|}{ Number of reads } \\
\hline & PDHS4 & PMHS8 & PUHS20 \\
\hline Megasphaera & 0 & 1 & 0 \\
\hline Oscillibacter & 0 & 2 & 0 \\
\hline Paenibacillus & 12 & 2 & 0 \\
\hline Phascolarctobacterium & 0 & 1 & 0 \\
\hline Propionispira & 1 & 7 & 0 \\
\hline Proteiniclasticum & 0 & 11 & 0 \\
\hline Proteocatella & 0 & 7 & 0 \\
\hline Pseudoflavonifractor & 0 & 1 & 0 \\
\hline Psychrobacillus & 1 & 5 & 0 \\
\hline Psychrosinus & 2 & 1 & 0 \\
\hline Ruminococcus & 0 & 1 & 0 \\
\hline Ruminococcus_g2 & 0 & 3 & 0 \\
\hline Ruminococcus_g5 & 0 & 3 & 0 \\
\hline Saccharibacillus & 0 & 1 & 0 \\
\hline Saccharofermentans & 0 & 2 & 0 \\
\hline Sedimentibacter & 0 & 1 & 0 \\
\hline Streptococcus & 1 & 3 & 0 \\
\hline Subdoligranulum & 1 & 1 & 0 \\
\hline Succinispira & 0 & 2 & 0 \\
\hline Trichococcus & 12 & 160 & 0 \\
\hline Ureibacillus & 1 & 1 & 0 \\
\hline Dethiobacter & 1 & 0 & 0 \\
\hline EF558947_g & 1 & 0 & 0 \\
\hline GQ480002_g & 1 & 0 & 0 \\
\hline HQ660796_g & 1 & 0 & 0 \\
\hline AF050591_g & 1 & 0 & 0 \\
\hline Bacillus & 27 & 0 & 0 \\
\hline EF404788_g & 1 & 0 & 0 \\
\hline Virgibacillus & 1 & 0 & 0 \\
\hline Alicyclobacillus & 1 & 0 & 0 \\
\hline Tumebacillus & 3 & 0 & 0 \\
\hline AB239481_g & 2 & 0 & 0 \\
\hline Anaerovorax & 1 & 0 & 0 \\
\hline Paenisporosarcina & 13 & 0 & 0 \\
\hline Eubacterium_g5 & 2 & 0 & 0 \\
\hline Eubacterium_g8 & 2 & 0 & 0 \\
\hline Sporosarcina & 1 & 0 & 0 \\
\hline DQ394658_g & 1 & 0 & 0 \\
\hline Dorea & 1 & 0 & 0 \\
\hline Turicibacter & 1 & 0 & 0 \\
\hline HQ716403_g & 1 & 0 & 0 \\
\hline AB298726_g & 1 & 0 & 0 \\
\hline DQ887956_g & 1 & 0 & 0 \\
\hline Planifilum & 1 & 0 & 0 \\
\hline Coprococcus & 2 & 0 & 0 \\
\hline AM500798_g & 1 & 0 & 0 \\
\hline AM277340_g & 2 & 0 & 0 \\
\hline GQ897654_g & 3 & 0 & 0 \\
\hline Sulfuricurvum & 0 & 0 & 1 \\
\hline Arcobacter & 0 & 0 & 34 \\
\hline Sulfurospirillum & 0 & 0 & 3 \\
\hline Total & 147 & 384 & 38 \\
\hline
\end{tabular}


Table S6. Detailed analysis of Cyanobacteria genus in hyporheic zones

\begin{tabular}{|c|c|c|c|}
\hline \multirow{2}{*}{ Genus } & \multicolumn{3}{|c|}{ Number of reads } \\
\hline & PDHS4 & PMHS8 & PUHS20 \\
\hline AB240501_g & 0 & 1 & 1 \\
\hline AB354619_g & 0 & 1 & 2 \\
\hline AJ536844_g & 0 & 1 & 0 \\
\hline AJ583204_g & 0 & 1 & 0 \\
\hline AY375144_g & 0 & 5 & 3 \\
\hline Chamaesiphon & 0 & 16 & 0 \\
\hline Chroococcus_g2 & 0 & 1 & 0 \\
\hline DQ128639_g & 1 & 1 & 2 \\
\hline EF032660_g & 0 & 2 & 0 \\
\hline EF580987_g & 0 & 1 & 0 \\
\hline EU101276_g & 0 & 3 & 0 \\
\hline EU491779_g & 0 & 1 & 0 \\
\hline FJ236035_g & 0 & 1 & 0 \\
\hline FJ425638_g & 0 & 1 & 0 \\
\hline FJ625338_g & 1 & 1 & 0 \\
\hline GQ451200_g & 0 & 2 & 2 \\
\hline HM124232_g & 0 & 1 & 0 \\
\hline JF733399_g & 0 & 2 & 0 \\
\hline Limnococcus & 0 & 46 & 0 \\
\hline Limnothrix & 0 & 3 & 1 \\
\hline Merismopedia & 0 & 3 & 0 \\
\hline Microcystis & 0 & 3 & 0 \\
\hline PCC7335_g & 0 & 1 & 0 \\
\hline Phormidium_g6 & 0 & 1 & 0 \\
\hline Pleurocapsa & 0 & 13 & 0 \\
\hline Prochlorococcus & 28 & 242 & 3 \\
\hline Snowella & 0 & 2 & 0 \\
\hline Vampirovibrio & 0 & 1 & 0 \\
\hline FJ543055_g & 1 & 0 & 0 \\
\hline GU444060_g & 5 & 0 & 0 \\
\hline EU134274_g & 1 & 0 & 0 \\
\hline AY493962_g & 4 & 0 & 0 \\
\hline EU753634_g & 5 & 0 & 0 \\
\hline AJ544083_g & 2 & 0 & 0 \\
\hline JF417809_g & 1 & 0 & 0 \\
\hline Woronichinia & 2 & 0 & 0 \\
\hline Nostoc_g1 & 1 & 0 & 0 \\
\hline Anabaena_g2 & 1 & 0 & 0 \\
\hline EF018129_g & 2 & 0 & 0 \\
\hline Nostoc & 2 & 0 & 0 \\
\hline JF737898_g & 4 & 0 & 0 \\
\hline Microcoleus & 1 & 0 & 0 \\
\hline Cylindrospermum & 1 & 0 & 0 \\
\hline FJ810552_g & 0 & 0 & 1 \\
\hline Total & 63 & 357 & 15 \\
\hline
\end{tabular}

Table S7. Detailed analysis of E-Proteobacteria genus in hyporheic zones

\begin{tabular}{|c|c|c|c|}
\hline \multirow{2}{*}{ Genus } & \multicolumn{3}{|c|}{ Number of reads } \\
\cline { 2 - 4 } & PDHS4 & PMHS8 & PUHS20 \\
\hline Arcobacter & 4 & 128 & 34 \\
\hline Sulfurospirillum & 1 & 57 & 3 \\
\hline JF747790_g & 0 & 2 & 0 \\
\hline Sulfuricurvum & 1 & 2 & 1 \\
\hline Total & 6 & 189 & 38 \\
\hline
\end{tabular}

Table S8. Detailed analysis of $\beta$-Proteobacteria genus in hyporheic zones

\begin{tabular}{|l|c|c|c|}
\hline \multirow{2}{*}{ Genus } & \multicolumn{3}{|c|}{$\%$ (number of reads) } \\
\cline { 2 - 4 } & PDHS4 & PMHS8 & PUHS20 \\
\hline AB294329_o & $0.09(1)$ & $0.00(0)$ & $0.00(0)$ \\
\hline AB308366_o & $7.05(74)$ & $0.35(6)$ & $0.15(5)$ \\
\hline Burkholderiales & $74.0(776)$ & $83.42(1,444)$ & $94.34(3,118)$ \\
\hline DQ009366_o & $1.33(14)$ & $0.17(3)$ & $0.03(1)$ \\
\hline DQ395705_o & $4.1(43)$ & $0.46(8)$ & $0.06(2)$ \\
\hline DQ469205_o & $0.00(0)$ & $0.06(1)$ & $0.03(1)$ \\
\hline EU786132_o & $4.39(46)$ & $0.4(7)$ & $0.15(5)$ \\
\hline Ferritrophicales & $0.00(0)$ & $0.06(1)$ & $0.00(0)$ \\
\hline Gallionellales & $1.53(16)$ & $0.29(5)$ & $0.00(0)$ \\
\hline Methylophilales & $2.76(29)$ & $1.33(23)$ & $0.06(2)$ \\
\hline Neisseriales & $1.04(11)$ & $5.03(87)$ & $2.23(74)$ \\
\hline Nitrosomonadales & $0.57(6)$ & $0.00(0)$ & $0.00(0)$ \\
\hline Rhodocyclales & $1.14(12)$ & $4.16(72)$ & $1.42(47)$ \\
\hline Sterolibacterium_o & $1.71(18)$ & $1.5(26)$ & $0.94(31)$ \\
\hline Thiobacillus_o & $0.00(0)$ & $0.06(1)$ & $0.00(0)$ \\
\hline Thiobacter_o & $0.09(1)$ & $0.12(2)$ & $0.00(0)$ \\
\hline Zoogloea_o & $0.19(2)$ & $2.59(45)$ & $0.57(19)$ \\
\hline Total & 1,049 & 1,731 & 3,305 \\
\hline
\end{tabular}


Table S9. Detailed analysis of Burkholderiales order in hyporheic zones

\begin{tabular}{|c|c|c|c|}
\hline \multirow{2}{*}{ Order } & \multicolumn{3}{|c|}{ Number of reads } \\
\hline & PDHS4 & PMHS8 & PUHS20 \\
\hline 4P000609_g & 1 & 1 & 5 \\
\hline 4P002413_g & 0 & 2 & 0 \\
\hline 4P003243_g & 0 & 2 & 0 \\
\hline AB076847_g & 2 & 1 & 1 \\
\hline AB240255_g & 49 & 0 & 0 \\
\hline AB672287_g & 9 & 1 & 0 \\
\hline Acidovorax & 7 & 49 & 96 \\
\hline Actimicrobium & 3 & 3 & 0 \\
\hline AF236011_g & 0 & 2 & 2 \\
\hline AF289156_g & 0 & 5 & 0 \\
\hline AF418942_g & 13 & 33 & 11 \\
\hline AJ565430_g & 0 & 7 & 8 \\
\hline AJ575697_g & 2 & 2 & 1 \\
\hline AJ863277_g & 13 & 7 & 4 \\
\hline Albidiferax & 11 & 25 & 28 \\
\hline AM777983_g & 55 & 5 & 0 \\
\hline Aquabacterium & 4 & 17 & 17 \\
\hline Aquincola & 4 & 0 & 1 \\
\hline AY218568_g & 6 & 7 & 19 \\
\hline AY234747_g & 182 & 1 & 0 \\
\hline AY328716_g & 0 & 2 & 0 \\
\hline Azohydromonas & 1 & 0 & 0 \\
\hline Bordetella & 0 & 2 & 0 \\
\hline Brachymonas & 0 & 4 & 0 \\
\hline Burkholderia & 18 & 0 & 1 \\
\hline Caenimonas & 10 & 1 & 0 \\
\hline Collimonas & 0 & 1 & 0 \\
\hline Comamonas & 6 & 322 & 1885 \\
\hline Cupriavidus & 4 & 1 & 0 \\
\hline Curvibacter & 6 & 35 & 9 \\
\hline Delftia & 0 & 1 & 0 \\
\hline Derxia & 0 & 0 & 4 \\
\hline DQ450176_g & 0 & 4 & 0 \\
\hline DQ469209_g & 0 & 1 & 0 \\
\hline DQ520167_g & 6 & 7 & 1 \\
\hline Duganella & 5 & 43 & 5 \\
\hline EF580985_g & 1 & 1 & 8 \\
\hline EU104128_g & 0 & 2 & 4 \\
\hline EU636042_g & 28 & 2 & 1 \\
\hline EU735703_g & 1 & 1 & 0 \\
\hline EU800906_g & 0 & 1 & 0 \\
\hline EU801607_g & 5 & 2 & 0 \\
\hline EU937973_g & 8 & 3 & 3 \\
\hline FJ517712_g & 9 & 8 & 4 \\
\hline FJ624877_g & 2 & 0 & 1 \\
\hline FJ660572_g & 0 & 4 & 5 \\
\hline FJ755754_g & 1 & 3 & 0 \\
\hline
\end{tabular}

Table S9. (continued)

\begin{tabular}{|c|c|c|c|}
\hline \multirow{2}{*}{ Order } & \multicolumn{3}{|c|}{ Number of reads } \\
\hline & PDHS4 & PMHS8 & PUHS20 \\
\hline FM209333_g & 0 & 6 & 0 \\
\hline FN668029_g & 0 & 4 & 1 \\
\hline Giesbergeria & 2 & 3 & 8 \\
\hline GU134931_g & 1 & 11 & 0 \\
\hline Herbaspirillum & 47 & 6 & 2 \\
\hline Herminiimonas & 29 & 2 & 0 \\
\hline HM445266_g & 2 & 0 & 0 \\
\hline HQ166641_g & 7 & 0 & 0 \\
\hline HQ178927_g & 6 & 1 & 0 \\
\hline HQ324854_g & 1 & 2 & 1 \\
\hline HQ910358_g & 1 & 0 & 0 \\
\hline Hydrogenophaga & 7 & 19 & 20 \\
\hline Ideonella & 9 & 23 & 4 \\
\hline Inhella & 1 & 3 & 0 \\
\hline Janthinobacterium & 12 & 30 & 25 \\
\hline JF697503_g & 1 & 3 & 1 \\
\hline JN679217_g & 4 & 16 & 1 \\
\hline Kinneretia & 1 & 1 & 0 \\
\hline Leptothrix & 8 & 24 & 11 \\
\hline Limnobacter & 0 & 2 & 0 \\
\hline Limnohabitans & 11 & 108 & 2 \\
\hline Malikia & 17 & 331 & 796 \\
\hline Massilia & 21 & 18 & 8 \\
\hline Methylibium & 1 & 3 & 0 \\
\hline Mitsuaria & 0 & 0 & 1 \\
\hline Oxalobacter & 0 & 1 & 0 \\
\hline Pandoraea & 0 & 1 & 0 \\
\hline Paucibacter & 2 & 12 & 8 \\
\hline Pelomonas & 0 & 5 & 4 \\
\hline Piscinibacter & 2 & 0 & 1 \\
\hline Polaromonas & 38 & 12 & 7 \\
\hline Polyangium_g1 & 1 & 0 & 0 \\
\hline Polynucleobacter & 9 & 86 & 5 \\
\hline Pseudoduganella & 0 & 0 & 2 \\
\hline Pseudorhodoferax & 2 & 3 & 17 \\
\hline Ralstonia & 2 & 5 & 0 \\
\hline Ramlibacter & 7 & 1 & 2 \\
\hline Rhizobacter & 9 & 10 & 2 \\
\hline Rhodoferax & 5 & 10 & 10 \\
\hline Rivibacter & 1 & 1 & 0 \\
\hline Simplicispira & 4 & 5 & 2 \\
\hline Sphaerotilus & 4 & 14 & 2 \\
\hline Sutterella & 0 & 2 & 0 \\
\hline Undibacterium & 5 & 24 & 45 \\
\hline Variovorax & 5 & 1 & 2 \\
\hline Xenophilus & 19 & 12 & 0 \\
\hline Z93984_g & 0 & 2 & 4 \\
\hline Total & 1,049 & 1,731 & 3,305 \\
\hline
\end{tabular}


Table S10. Detailed analysis of Bacteroidetes genus in hyporheic zones

\begin{tabular}{|c|c|c|c|}
\hline \multirow{2}{*}{ Genus } & \multicolumn{3}{|c|}{ \% (number of reads) } \\
\cline { 2 - 4 } & PDHS4 & PMHS8 & PUHS20 \\
\hline Bacteroidia & $1.33(6)$ & $31.96(326)$ & $3.4(60)$ \\
\hline Cytophagia & $4.87(22)$ & $6.18(63)$ & $0.28(5)$ \\
\hline Flavobacteria & $11.5(52)$ & $36.76(375)$ & $93.15(1,645)$ \\
\hline Sphingobacteria & $82.3(372)$ & $25.1(256)$ & $3.17(56)$ \\
\hline Total & 452 & 1,020 & 1,766 \\
\hline
\end{tabular}

